\title{
Ancient patronage: A possible interpretative context for Luke 18:18-23?
}

\begin{tabular}{|c|c|}
\hline \multicolumn{2}{|c|}{$\begin{array}{l}\text { Authors: } \\
\text { Kingsley I. Uwaegbute }{ }^{1,2} \\
\text { Damian O. Odo }\end{array}$} \\
\hline $\begin{array}{l}\text { Affiliations: } \\
{ }^{1} \text { Department } \\
\text { Cultural Studie } \\
\text { Social Science } \\
\text { of Nigeria, Nsu }\end{array}$ & $\begin{array}{l}\text { f Religion and } \\
\text { es, Faculty of } \\
\text { s, University } \\
\text { kka, Nigeria }\end{array}$ \\
\hline $\begin{array}{l}{ }^{2} \text { Department } \\
\text { Testament and } \\
\text { Literature, Fac } \\
\text { Theology and } \\
\text { University of P } \\
\text { Pretoria, Sout }\end{array}$ & $\begin{array}{l}\text { f New } \\
\text { Related } \\
\text { ulty of } \\
\text { Religion, } \\
\text { retoria, } \\
\text { n Africa }\end{array}$ \\
\hline $\begin{array}{l}\text { Research Proje } \\
\text { Project Leader } \\
\text { Project Numb }\end{array}$ & $\begin{array}{l}\text { ct Registration: } \\
\text { r: E. van Eck (1) } \\
\text { er: } 2400030\end{array}$ \\
\hline $\begin{array}{l}\text { Description: } \\
\text { The authors ar } \\
\text { in the research } \\
\text { Platform for N } \\
\text { directed by Prc } \\
\text { van Eck, Depar } \\
\text { Testament and } \\
\text { Literature, Fac } \\
\text { Theology and } \\
\text { University of P }\end{array}$ & $\begin{array}{l}\text { e participating } \\
\text { project 'Africa } \\
\text { T Scholars' } \\
\text { of. Dr Ernest } \\
\text { rtment of New } \\
\text { Related } \\
\text { ulty of } \\
\text { Religion, } \\
\text { retoria. }\end{array}$ \\
\hline $\begin{array}{l}\text { Corresponding } \\
\text { Damian Odo, } \\
\text { damian.odo@ }\end{array}$ & $\begin{array}{l}\text { g author: } \\
\text { unn.edu.ng }\end{array}$ \\
\hline $\begin{array}{l}\text { Dates: } \\
\text { Received: } 17 \mathrm{D} \\
\text { Accepted: } 17 \\
\text { Published: } 01\end{array}$ & $\begin{array}{l}\text { ec. } 2020 \\
\text { Mar. } 2021 \\
\text { July } 2021\end{array}$ \\
\hline $\begin{array}{l}\text { How to cite th } \\
\text { Uwaegbute, K. } \\
\text { 2021, 'Ancient } \\
\text { A possible inte } \\
\text { context for Lul } \\
\text { HTS Teologiese } \\
\text { Theological St } \\
\text { a6427. https:// } \\
\text { org/10.4102/h }\end{array}$ & $\begin{array}{l}\text { is article: } \\
\text { l. \& Odo, D.O., } \\
\text { patronage: } \\
\text { rpretative } \\
\text { ke 18:18-23?', } \\
\text { Studies/ } \\
\text { udies 77(1), } \\
\text { /doi. } \\
\text { its.v77i1.6427 }\end{array}$ \\
\hline $\begin{array}{l}\text { Copyright: } \\
\text { C 2021. The A } \\
\text { Licensee: AOSI } \\
\text { is licensed und } \\
\text { Creative Comn } \\
\text { Attribution Lic }\end{array}$ & $\begin{array}{l}\text { Iuthors. } \\
\text { IS. This work } \\
\text { ler the } \\
\text { nons } \\
\text { ense. }\end{array}$ \\
\hline 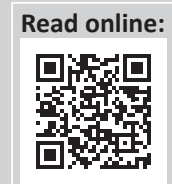 & $\begin{array}{l}\text { Scan this QR } \\
\text { code with your } \\
\text { smart phone or } \\
\text { mobile device } \\
\text { to read online. }\end{array}$ \\
\hline
\end{tabular}

Authors:

Affiliations:

${ }^{1}$ Department of Religion and Cultural Studies, Faculty of Social Sciences, University , Nsukka, Niger

Department of New

Literature, Faculty of

Theology and Religion,

University of Pretoria,

Research Project Registration: Project Leader: E. van Eck (D)

The authors are participating in the research project 'Afric van Eck, Department of New Testament and Related Theology and Religion, Corresponding author: Damian Odo,

Dates:

Received: 17 Dec. 2020 Accepted: 17 Mar. 2021 Published: 01 July 2021

How to cite this article: 2021, 'Ancient patronage: A possible interpretative HTS Teologiese Studies/ Theological Studies 77(1), a6427. https://doi.

Copyright: Licensee: AOSIS. This work is licensed under the Creative Commons Attribution License.

Read online: to read online.
Against the conventional reading of Luke 18:18-23 as a micro-narrative that revolves around discipleship and the dangers of wealth with regard to inheriting the Kingdom of God, this article reads the text using patronage (and clientism) as a model. It argues that this micronarrative also mirrors patronal relations in the 1st-century Roman Palestine through which a few elites exploited the majority poor. The description of the chief protagonist in the narrative as a ruler, who was also rich, by Luke casts him in a negative light as a patron who exploited the poor around him who were his clients. From this standpoint, it is therefore argued in the article that the strategy of the narrative is to encourage patrons to move from negative and balanced reciprocity to 'general reciprocity' in which giving to the poor without the desire to receive back dominates. This interpretation is still within the framework of the theology of wealth in the Gospel of Luke, which encourages 'giving without the expectation to receive back'.

Contribution: This article argues that the micro-narrative of Luke 18:18-23 mirrors patronal relations of 1st-century Palestine. From Luke's description of rich ruler, the first hearers of Luke probably thought of him as a patron who exploited his clients, the poor. The call by Jesus to self-divesture therefore is a call for patrons to move beyond negative and balanced reciprocity to practice general reciprocity in which giving to the poor, without the want to receive back, dominates; this is social-scientific criticism of Luke 18:18-23 mostly neglected in Lukan scholarship.

Keywords: Luke 18:18-23; patronage/clientism; exploitation; Jesus; general reciprocity; wealth ethics.

\section{Introduction}

Luke 18:18-23 is not particularly Lukan because it has parallels in both Mark 10:17-31 and Matthew 19:16-30. These parallels, and that of Luke, in conventional readings, deal with the question of inheriting eternal life equated with entering the Kingdom of God which is to come. In this text (Lk 18:18-23), a rich ruler enquired from Jesus on what he needed to do so as to inherit eternal life. According to Bailey (1983:159), 'in the opening stanza the rich young ruler wants to do something to gain eternal life as an inheritance'. It is therefore because of the ruler's zeal to do something and gain eternal life that Jesus gave him an answer. For Porter (1988:1218), Jesus' answer suggests superfluity because the requirements are encoded in the Decalogue. As Karris (1990:710) pointed out, the law, particularly the love of God and neighbour, shows that the Decalogue contains the requirement for eternal life as Jesus demonstrated in Luke 10:25. Answering from a deeper conviction, the rich ruler told Jesus that he had observed all the Ten Commandments right from youth. However, Jesus demands that he goes one-step further; he must sell his possessions and give the proceed to the poor for him to have treasures in heaven. It is only on this condition that he can be a disciple of Jesus. On hearing this, the rich ruler went away with a heavy heart. In this conventional reading, possessions are presented as an obstacle to discipleship, hence blocking the rich's entrance into the kingdom of God.

This article proposes to read this micro-narrative from another perspective to uncover its other aspects and show how this can help illuminate the text better. To do this, social-scientific criticism will be applied to the text, using patronage (and clientism) as a model. In this article, it will be argued that the micro-narrative also mirrors patronal relations between the rich and the poor of the 1st-century world of Palestine marred by exploitation. It is in this regard that it will be shown that the rich ruler was a patron who exploited the poor, acquired his wealth and failed to take care of the poor under and around him. Our reading of the text, at the end, will still be consistent with

Note: Special Collection: Africa Platform for NT Scholars, sub-edited by Ernest van Eck (University of Pretoria). 
the overall Lukan wealth ethics in which the sharing of possessions with the poor is at the fore, together with the humanisation of the relationship between these two classes of people. It is good to point out that our reading of the text has its own bias and may appear reductionist in some sense. However, we are inclined to believe that an original research is meant to prove a point, whether it is reductionist or not, with regard to its subject of study.

\section{Patronage: A dominant social relationship in the 1st-century Mediterranean world}

According to Block (1969), patronage is:

[A] model or analytical construct which the social scientist applies in order [to] understand and explain a range of apparent different social relationships: father-son, God-Man, Saintdevotee, godfather-godchild, lord-vassal, landlord-tenant, professor-assistant, and so forth. (p. 366)

\section{Similarly, Lande (1977) said that:}

$[P]$ atron-client relationship is a vertical dyadic alliance, that is an alliance between two persons of unequal status, power or resources each of whom finds it useful to have as an ally someone superior or inferior to himself. (p. 20)

This type of relationship is also called patron-client relationship and is used interchangeably. Neyrey (2004:249) said that patron-client relationship describes the vertical dimension of exchange between higher and lower-status people. For Moxnes (1991:242) patron-client relationships are social relationships between individuals based on strong element of inequality and difference in power. The basic structure of the relationship is an exchange of different and very unequal resources. Eisenstadt and Roniger (1984) classified patronclient relations into: (1) asymmetrical relationship that exist between parties of different status, that is, inferior and superior relationship, (2) simultaneous exchange of varying types of resources, both economic and political where the patron offers these resources and clients respond with promises, reciprocity, solidarity and loyalty, (3) interpersonal obligation that deals with personal loyalties or attachment patrons and clients, (4) favoritism, (5) kinship glaze in which patrons become fathers to their clients, (6) honour which is both given and received between patrons and clients. ${ }^{1}$

Whilst some of the poor voluntarily entered into such relationships (Santos 2008), most were forced into it owing to debts - the inability to repay high interest loans taken from patrons that led to loss of land, which was the only source of livelihood for the peasants (Eisenstadt \& Roniger 1984:208; Fiensy 1991; Goodman 1987:55-59; Oakman 1991; Van Eck $2009 b$ ). For the patrons, the basic motivation for this relationship was the accumulation of wealth, honour and respect gained through exploitation of the poor (WallaceHadrill 1989:64). Hence, Silverman (1977) told us that in patron-client relationship of the Mediterranean world:

1.See also Neyrey (2005:465-466) for other features of patronage in the 1st century.
[I]deas about appropriateness might as well include the expectation that patrons will often not do what they are supposed to. It may be expected, for instance, that they will abuse their positions or exploit their clients while adopting manners and languages of paternalism. (p. 10)

In a similar way, Moxnes (1991:248) wrote of patron-client relationship that 'inequality and asymmetry in power are combined with expressions of mutual solidarity, potential coercion and exploitation from the patron is considered with apparently voluntary relations and mutual obligations'. Equally, Shelton (1988:13-14) said that patronage ensured that the 'upper class and lower class were bound to one another in relationships which emphasised deference and obsequiousness on the part of many towards a few'. Other scholars such as Goodman (2007), Lorencin (2007), Baker (2010) and Bindell (2013) equally acknowledged the demeaning and exploitative nature of patron-client relationships in the Roman empire.

For honour and respect in the patrons' view, they must be publicly displayed and acknowledged by the poor. ${ }^{2}$ As Abiji and Etukumana (2018) wrote:

$[A]$ nyone who received such benevolence accepted the obligation to publicly proclaim his/her gratitude for the generosity of his/ her benefactor, thereby promoting and enhancing the reputation of the patron. In this way, the patron helped to enhance the reputation of the patron. (p. 14)

This was why there was competition for acquiring clients because the more clients a patron had, the more honour he received publicly (Uwaegbute 2019a:110). All these show how exploiting this relationship was in such a peasant society.

This kind of relationship was characteristic of Palestine in the New Testament time(s) (Heen 2006), which was an advanced agrarian society. Exploitation was characteristic of that world; the few elites of that world exploited the poor masses as they deemed fit. Studies on the sociopolitical world of Palestine during the New Testament time confirm this fact (Goodman 1987; Häkkinen 2016; Hanson \& Oakman 1998; Horsley 1987, 2006; Malina 1988; Oakman 1986, 1991, 2008a, 2008b, 2014; Van Eck 2009a, 2009b).

In Palestine of that time, subsistence and poverty were the lot of the masses not belonging to the elite class. Whilst there were various means through which the few elites of Palestine exploited the poor masses, patronage ranked as a veritable source of exploitation and domination of the poor in that world. It is therefore in this regard that patron-client relationship became a dominant form of relationship between the elites and the peasants, which is also mirrored, for example, in the Gospel of Luke (Reich 2011:33-34). Most of the patrons of Palestine were ungenerous to their clients, the poor; they were only out to exploit and extract from their clients the more for their selfish interests. In the gospels, we come across such patron-client relationship and how they

2.As suggestive in the teaching on leadership by Jesus in Luke $22: 25-27$, patronbenefactor/client relationship smacks of domination and high-handedness. 
functioned particularly as characterised by exploitation and Jesus' critique of it (Malina 1988:1-32; Megbelayin 2001:192; Moxnes 1988: 36-47, 62-64). ${ }^{3}$

\section{Re-reading Luke 18:18-23 in the context of patronage in the 1st- century Roman Palestine}

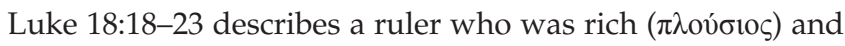
probably of the Jewish stock, asking Jesus for requirements for gaining eternal life. This enquiry, as Barret (2012:80) said, is a genuine question from the ruler. The description of this character as a ruler, and wealthy, is very important to the development and understanding of this text particularly, in our present reading of the text in the context of patronage. This description, of course, casts the ruler as a negative character (Bock 2006:1476). However, before proceeding, it is deemed important to describe our use of the terms 'rich (wealthy)' and 'poor (peasant)', being aware of the complexities surrounding their usages in antiquity, particularly in the Mediterranean context. For sure, the use of these terms in binary context has proven not to help our understanding of them in the context being discussed. Hence, the article will adopt Friesen's (2005) ${ }^{4}$ seven-point scale of poverty in Roman Empire in describing both the rich and poor in this article. In a tabular form, Friesen's poverty scale can be represented in Table 1.

From this scale, we can better understand who the terms 'rich' and 'poor' applied to in the Roman Empire at the time being discussed. Whilst the term 'rich' would generally apply to people within PS1 to PS3, it applies specifically, in our own usage, to those in PS2 and PS3. The poor would then include people within PS6 and PS7, respectively. As seen in the above scale, their percentages (PS6/PS7) are on the high side of the population. That being said, the character that Luke describes as a ruler and rich would have belonged to PS2 or PS3. In the previous subsection, the aspects of socio-economic conditions of Palestine during the New Testament time dominated by patronage and characterised by exploitation were brought to the fore. Within the context of Palestine where Jesus operated, local patrons would be identified amongst people within PS $2 / 3$ and they were very few as well. On the contrary, as Hays (2012:48) pointed out, the vast majority of the Palestinian population at that time were the poor.

In Luke, examples of patrons identifiable within these scales (2 and 3) are mentioned in 7:1-5, 8:1-3 and 16:19. Hence, by describing this character as a ruler, we can infer that he was a patron who, of course, was wealthy; a description that struck a negative chord in the minds of most poor people of Palestine. This is very probable because Luke assumes that

3.For an opposing view, see Ascough (2010:600). However, a lot of material in the Gospe of Luke suggests his awareness of the existence of patron-client relationships in Palestine of the time of J Palestine of the time of Jesus as we see in Luke 22:25,7:2-10, 16:19. With regard to patronage in Pauline and other General Epistles contexts, see Chow (1992:188), Davids
(1982) Meeks $(1983: 78,98,119)$ and Vyhmeister (1995:265-283), amongst others.

4.Longenecker (2010) follows the seven-point scale of Friesen although disagreeing with him on percentages of people belonging to different scales. For a similar scale, see King (2019:168-169)
TABLE 1: Seven-point scale of poverty in Roman Empire.

\begin{tabular}{|c|c|c|c|}
\hline PS1 & Imperial elites & $\begin{array}{l}\text { Imperial dynasty, Roman } \\
\text { senatorial families, a few } \\
\text { retainers, local royalty, a few } \\
\text { freed persons }\end{array}$ & $0.04 \%$ \\
\hline PS2 & $\begin{array}{l}\text { Regional or provincial } \\
\text { elites }\end{array}$ & $\begin{array}{l}\text { Equestrian families, provincial } \\
\text { officials, some retainers, some } \\
\text { decurial families, some freed } \\
\text { persons, some retired military } \\
\text { officers }\end{array}$ & $1.00 \%$ \\
\hline PS3 & Municipal elites & $\begin{array}{l}\text { Most decurial families, wealthy } \\
\text { men and women who do not } \\
\text { hold office, some freed persons, } \\
\text { some retainers, some veterans, } \\
\text { some merchants }\end{array}$ & $1.76 \%$ \\
\hline PS4 & $\begin{array}{l}\text { Moderate surplus } \\
\text { resources }\end{array}$ & $\begin{array}{l}\text { Some merchants, some traders, } \\
\text { some freed persons, some } \\
\text { artisans (especially those who } \\
\text { employ others) and military } \\
\text { veterans }\end{array}$ & $7 \%$ \\
\hline PS5 & $\begin{array}{l}\text { Stable near subsistence } \\
\text { level (with reasonable } \\
\text { hope of remaining } \\
\text { above the minimum } \\
\text { level to sustain life) }\end{array}$ & $\begin{array}{l}\text { Many merchants and traders, } \\
\text { regular wage earners, artisans, } \\
\text { large shop owners, freed } \\
\text { persons, some farm families }\end{array}$ & $22 \%$ \\
\hline PS6 & $\begin{array}{l}\text { At subsistence level } \\
\text { (and often below } \\
\text { minimum level to } \\
\text { sustain life }\end{array}$ & $\begin{array}{l}\text { Small farm families, labourers } \\
\text { (skilled and unskilled), artisans } \\
\text { (especially those employed by } \\
\text { others), wage earners, most } \\
\text { merchants and traders, small } \\
\text { shop/tavern owners }\end{array}$ & $40 \%$ \\
\hline PS7 & $\begin{array}{l}\text { Below subsistence } \\
\text { level }\end{array}$ & $\begin{array}{l}\text { Some farm families, unattached } \\
\text { widows, orphans, beggars, } \\
\text { disabled, unskilled day } \\
\text { labourers, prisoners }\end{array}$ & $28 \%$ \\
\hline
\end{tabular}

Source: Adapted from Friesen, S.J., 2005, 'Poverty in Pauline studies: Beyond the so-called New consensus', JSNT 26, 323-361. https://doi.org/10.1177/0142064X0402600304

his audience was very familiar with most rulers/wealthy people in Palestine being patrons. This is the point Hays (2012:55) made about this ruler when he argued that in Palestine of Jesus's time, rulers and the rich are one and the same. And as has been pointed out above, most rich people and rulers functioned as patrons in that world. It is within this context that Luke carefully added that this character was a ruler, an addition which the parallels in Mark 10:17-31 and Matthew19:16-30 omit. This is a fact that Hays (2010:172-174), Johnson (1991:280), Schottroff and Stegemann (1986:191-192) and King (2019:109) agreed on by saying that Luke purposely described this interlocutor as a ruler and rich to intensify his message on wealth ethics. Equally important to our argument here is Luke's omission of Mark 10:21 record that Jesus looked at the rich man and loved him. In fact in Mark's record, it seems that Jesus' response to the rich man to sell all his possession and give them to the poor so as to have treasure in heaven was borne out of Jesus' love for him. Luke could not have recorded what Mark 10:21 has because, to him, the rich ruler was a patron, a negative character and as such did not deserve Jesus' love. These omissions tell us what both Jesus and Luke thought about exploiting patrons.

Beyond this, it is important to note that Luke's description of the character as wealthy tells us much about Mediterranean conception of the rich by peasants at that time. Amongst the peasants of that world, as Malina (1987:355) pointed out, wealthy or rich simply means 'avaricious' 'greedy'. It also connoted exploitation (1991:255).

As Malina (1987:355) added, peasant societies (to which Palestine belonged) saw all resources in terms of limited goods and therefore saw all wealthy people as thieves who 
had benefitted at the expense of the poor. And this character that Luke described was a ruler, although undefined. Block (1996:1476) dismissed the idea that this ruler was a Pharisee because Luke would not have hesitated in describing him as such. Rather, Bock suggests that he was a magistrate or an official of the high priest. We equally follow Bock's line of argument by saying that this character probably belonged to the upper class of the Jewish society, and in this regard, had some form of association with the religious leadership of the Jews. Our argument rests on the ruler's claim in v21 that he had kept all the commandments from his youthful days, probably as from 13 years old when he became a bar mitzvah [son of the law]. This was a time from which it is required that a Jewish youth becomes responsible to keep the law. His answer showed that he was very pious, especially as defined from the perspective of obedience to the law and his own personal conviction (selfrighteousness); this is a claim that any religious leader of Israel was likely to make at that time as we saw in the case of Paul in Philippians 3:6. Equally, this argument would not be out of place considering that Luke, particularly, has a way as associating ö $\rho \chi \omega v$ [rulers] with the priests, an indication that they had a place in religious leadership of Israel at the time of Jesus (see Lk 8:41,14:1, 23:13,15, 24:20, Ac 3:17,4:5,8, 13:27,14:5).

The Jewish upper class at that time, which also included the priestly and the religious class, was as exploitative as other 'secular' elites. As Goodman (1987:59-66) and Van Eck (2009:353) argued, the priestly class of Israel during the time being discussed was so wealthy to the point that they could not spend their resources via consumption and the building of expensive houses. This meant that they always looked out for opportunities to invest. One such investment was extending credit facility to small farmers who were a veritable source of income. This credit facility is not to be seen as generosity by these people. No, it was purely business - an avenue through which this class of people acquired land(s) of the peasants when they failed to repay their loans. Enslavement was the end result of this failure, with most peasant farmers becoming property of their new masters (Goodman 1987:59-66; Van Eck 1991:255, 2009:353). Hence, most of the Jewish upper class, including the religious leaders, were patrons who exploited the peasants. Therefore, by describing this character as a ruler, and wealthy, we can infer what Luke's audience thought about him: he was a patron who exploited the poor under and around him. This is why Patella (2009:255) is right in describing this ruler as a man who made his 'wealth through his wits'.

Jesus, coming from the peasant class and identifying heavily with it, knew who the rich ruler really was. So, no amount of 'knowing and practising' the Ten Commandant will absolve him of this great evil - exploitation of the peasants. However, testing him, Jesus offered him a chance to atone for his evil and divest himself of all his ill-gotten wealth. Hence, he was asked by Jesus to sell all he had acquired and share the proceeds with the exploited poor (the rightful owner of the wealth). The poor, represented as $\pi \tau \omega \chi 01 \varsigma$ here, and from our poverty scale, were those in the 1st century who were scarcely able to maintain their honour or dignity (Malina 1987:355).

Furthermore, the poor refers to those who could not maintain their inherited status because of circumstance and fate that befall their families. These included debts, displacement/ being in foreign land, sickness/physical accidents, including those who thirsted and hungered and those with infirmities (Malina 1981:85). By demanding that the ruler sold all he had and shared the proceeds with the poor, Jesus wanted the ruler to take responsibility expected of him as a patron. This was a radical call to self-divestiture for the benefit of the poor of the society, which both Jesus and Luke envisioned. Hence, according to Metzger (2007), Schottroff and Stegmann (1986), King (2019), Hays (2010) and Brown (2014), Jesus' saying here is a radical call to the renunciation of possessions extended to the rich ruler. ${ }^{5}$ This command is for the rich ruler to take responsibility of those under him in a way that was even far better than what was obtainable in his world then. It is a radical call to practise general reciprocity, which entailed giving (to the poor) without the desire to receive. This radical call is not to be overshadowed by Jesus' emphasis on self-divestiture, which was not a character expected of patrons at that time. Rather, the emphasis is on the need for patrons practise general reciprocity by sharing their wealth with the poor even if it means self-divesture. This is the point Hays (2010:172-174) makes when he writes that by calling the ruler to selfdivestiture 'Jesus is seeking first an equitable redistribution of essential resources for the benefit of the poor'. And as we have seen, access to essential resources of Palestine was being controlled by a few elites who were in tune with local patrons.

This is a better understanding than that of Utley (1996:n.p.), which says that 'the issue here is not the poor as a social problem'.

It is in the above context that the injunction to the ruler equally envisioned the humanisation of the relationship that should exist between the rich and the poor in his society through equitable distribution of resources. Hence, by calling the ruler to share his wealth with the poor, Jesus was at the same time envisioning a context where the relationship between the rich and the poor is made more humane, contrary to what was obtainable in Palestine of his day as by the few elites of that world. But, typical of most patrons of that world, the ruler's greed, avariciousness and love of wealth got the better of him. He went away dejectedly, refusing Jesus's offer and failing in Jesus's quest to reorganise the society by living up to his expected role as a patron who should take good care of his clients and other peasants around him. Although patrons of the Mediterranean world at that time tended to be exploitative, there were, however, examples of those who took responsibility to take good care of their clients and the peasants around them. Examples are seen from secular sources and even from the gospel of Luke and Acts of the apostles. From a secular source, we learn about the case of Dio Chrysostom, a leader in Prusa, an ancient city of Greece. In Oratio, Dio described

5.For a contrary view, see Phillips (2001), Seccombe (1982). 
his being mobbed and accused of holding back his own wealth instead of using it for public good. Dio refuted this accusation, showing that he in fact behaved honourably. According to him, there were honourable behaviour towards the poor and this was what he did. Although he was a rich landowner, he did not deprive his poor neighbours of their possessions or evict them from their smallholdings (Chrysostom, Oratio 46:7-8). This is glimpse of how a patron should behave to the poor in peasants' eyes and their cultural conventions. Another glimpse of such commendable act of a patron is seen in Luke 7:1-10 involving a centurion living in Capernaum. Although a non-Jew, the centurion's honourable behaviour to the peasant villagers of Capernaum earned him great praises before Jesus on being deserving for his son to be healed by Jesus. Another related incident involved the case of Zacchaeus, the wealthy taxcollector at Jericho. Although not a patron, he was commended by Jesus on his willingness to pay back those he had exploited to make his wealth (Lk 19:1-10). Looking further afield in Luke's second volume, the Acts of Apostles, we still find patrons who exhibited behaviours expected of patrons. In Acts 16:14-15, we read the story of Paul's relationship with a patron called Lydia. According to Moxnes (1991:262), Paul's relationship with Lydia depicts 'a complex patron-client relationship'. From the narrative Lydia, a seller of purple goods from Thyatira, out of her generosity offered his house to Paul to stay. Giving her house to Paul to stay could also mean that her house became a house church. Equally, as Bindell (2013:5-6) suggested, the mention of Lydia's household in the narrative could mean that she had a circle of clients. Thus, she was indeed a patron and her act of generosity is deserving a behaviour expected of patrons in Jesus' teaching. Another such act deserving a patron is recorded in Acts 17:1-9. Here a probable patron named Jason who may have been a Jew (cf. Rm 16:21). Jason incurred the wrath of the 'unbelieving' Jew in Thessalonica for his act of generosity in hosting Paul and his missionary party. The fact that Jason was able to host Paul and his party, in addition to posting bond for both Paul and his party, indicates that he (Jason) was prosperous, wealthy and influential. These equally cast a light on him as a patron. All these characters, shown from both the Gospel of Luke and Acts of the Apostles, therefore, represent a model of patrons who take responsibility for their position as patrons.

The case of the rich ruler is a stark contrast to this model of patrons. It is not in line with Jesus' ideal of general reciprocity, which is how a patron should behave towards the poor under and around him. ${ }^{6} \mathrm{He}$ (the rich ruler) blatantly refused to share his wealth with the poor whom he exploited to make his wealth in the first place. This then brings us to the core of the text from a patronal dynamic: patrons should take responsibility and share their resources with their clients and other poor persons around them. This is to be done by practising general reciprocity in which giving without the expectation to receive stands out. This will also help to humanise the relations between the rich and the poor as envisioned by Jesus and the Gospel of Luke.

6.The rich ruler's act relates to that of the rich fool recorded in Luke 12:13-21 who also refused to share the proceed of his farm with the poor.

\section{Concluding the reading of the text}

Our reading of the text through the lens of patronage provides us with cultural scripts, perceptions and conventions that abounded in the world of Jesus. That world was an advanced agrarian society where very few elites (aristocrats) lorded it over the peasants. It was a world where patronage was a common social relationship characterised by exploitation. Patrons, most times, exhibited negative reciprocity, which had only their selfish interest at heart. In this sense, by asking the rich ruler to sell all he has and give the proceeds to the poor, the strategy of the text from a patronage lens is to denounce the exploitation of peasants by tasking patrons to live up to their responsibility by sharing their resources with the poor who are mostly their clients. By implication, this was a call for patrons to practise general reciprocity through taking care of their clients (the poor) without any form of wanting to receive back. Relatedly, this interpretation underscores the need for the humanisation of the relationship between the rich and the poor. In all this, we see an interpretation of Luke 18:18-23 that is in line with the overall theology of wealth in Luke, which deals with the sharing of wealth amongst the poor by the wealthy without expecting to receive (Coleman 2018; Esler 1987; Hays 2010; Johnson 2011; Kim 1993; King 2019; Kruger 2005; Metzger 2007; Ngele, Uwaegbute \& Odo 2017; Pilgrim 1981; Uwaegbute 2019b). ${ }^{7}$

\section{Acknowledgements Competing interests}

The authors declare that they have no financial or personal relationships that may have inappropriately influenced them in writing this article.

\section{Authors' contributions}

Both authors contributed equally to this article.

\section{Ethical considerations}

This article followed all ethical standards for research without direct contact with human or animal subjects.

\section{Funding information}

This research received no specific grant from any funding agency in the public, commercial or not-for-profit-sectors.

\section{Data availability}

Data sharing is not applicable to this article as no new data were created or analysed in this study.

7.Our interpretation here does not exclude the possibility of gleaning, from the text a new form of patron-client relationship based on heavenly treasures. By a new form of patron-client relationship based on heavenly treasures. By implication, Jesus' interaction with the rich ruler may suggest the idea that the rich ruler saw Jesus as a patron with heavenly riches, which he wants to access. However within the context of patron-client relationship and its application to New Testament texts, Jesus cannot be a patron but a broker through which God, the patron, is accessed. This is a problem associated with such an interpretation of the text. Besides, such a reading of the text is beyond the aim of this article. 


\section{Disclaimer}

The views and opinions expressed in this article are those of the authors and do not necessarily reflect the official policy or position of any affiliated agency of the authors.

\section{References}

Abiji, O.M. \& Etukumana, G., 2018, 'Leadership, violent conflict, and reconciliation in Africa: The theological-sociocultural engagement of Luke's gospel in socia transformation', Stellenbosch Theological Journal 4(1), 11-37. https://doi. org/10.17570/stj.2018.v4n1.a01

Ascough, R.S., 2010, 'Jesus, patrons and benefactors: Roman Palestine and the gospel of Luke (reviewed)', CBQ 72(3), 599-601.

Bailey, K., 1983, Poet and peasants and through peasant eyes, WB Eerdmans, Grand Rapids, MI.

Baker, C.A., 2010, 'Identity, memory, and prototypicality in early Christianity: Peter, Paul, and recategorization in the Acts of the Apostles', PhD dissertation, Brite Divinity School.

Barret, K.S., 2012, 'Justification in Lukan Theology', PhD dissertation, The Southern Baptist Theological Seminary.

Bindell, D., 2013, Patrons and clients, Paper for Oxford Institute Biblical Studies Working Group, viewed n.d, from https://omits.files.wordpress.com.

Blok, A., 1969, 'Variations in patronage', SociologischeGide Xvi, 365-378.

Bock, D.L., 1996, Luke 9:51-24:53, Baker, Grand Rapids, MI.

Brown, R.E., 2014, An introduction to the New Testament, TPI, Bangalore.

Coleman, R.L., 2018, 'The Lukan lens on wealth and possessions: A perspective shaped by the themes of reversal and right response', PhD dissertation, Regent University.

Chow, J., 1992, Patronage and power, JOST Press, Sheffield.

Davids, P.H., 1982, The epistle of James: A commentary on the Greek Text, Eerdmans, Grand Rapids, Ml.

Eisenstadt, S.N. \& Roniger, L., 1984, Patrons, clients and friends: Interpersonal relation and the structure of trust in society, Cambridge University Press, Cambridge.

Esler, P.F., 1987, Community and Gospel in Luke-Acts: The social and political motivations of Lucan Theology, Cambridge University Press, Cambridge.

Fiensy, D., 1991, The social history of Palestine in the Herodian period: The land is mine, Mellon, New York, NY.

Friesen, S.J., 2005, 'Poverty in Pauline studies: Beyond the so-called New consensus', JSNT 26, 323-361. https://doi.org/10.1177/0142064X0402600304

Goodman, M., 1987, The ruling class of Judaea, Cambridge University Press, Cambridge.

Goodman, M., 2007, Rome and Jerusalem: The clash of ancient civilization, Penguin, London.

Häkkinen, S., 2016, 'Poverty in the first-century Galilee', HTS Teologiese Studies/ Theological Studies72(4) 1-9. https://doi.org/10.4102/hts.v72i4.3398

Hanson, K.C \& Oakman, D.E., 1998, Palestine in the time of Jesus: Social structures, and social conflicts, Fortress, Minneapolis, MN.

Hays, C.M., 2010, Luke's wealth ethics: A study in their coherence and character, Mohr Siebeck, Tübingen.

Hays, J.D., 2012, 'Sell everything you have and give to the poor: The Old Testament prophetic theme of justice as the connecting motif of Luke 18:1-19:10', JETS 55(1), 43-63.

Heen, E.M., 2006, 'Radical patronage in Luke-Acts', Currents in Theology and Mission $33(6), 445-458$.

Horsley, R.E., 1987, Jesus and the spiral of violence, Harper Collins, San Francisco, CA.

Horsely, R.E., 2006, 'Early Christian movements: Jesus movements and the renewal of Israel', HTS Theological Studies 62(4), 1201-1225, viewed 10 June 2020, from https://hts.org.za/index.php/hts/article/view/410/310.

Johnson, L.T., 1991, The Gospel of Luke, Sacra Pagina, The Liturgical Press, Collegeville, PA.

Johnson, L.T., 2011, Sharing possessions: What faith demands, Eerdmans, Grand Rapids, MI.

Karris, R.J., 1990, 'Luke', in R.E. Brown, J.A. Fitzmyer \& R.E. Murphy (eds.), The New Jerome Bible Commentary, pp. 65-721, Prentice Hall, Englewood Cliffs, NJ.

Kim, K-J., 1993, 'Stewardship and almsgiving: A study of Luke's theology of wealth', $\mathrm{PhD}$ thesis, University of Glasgow.

King, D.D.M., 2019, 'Reclaiming the radical economic message of Luke', PhD dissertation, University of Denver.

Kruger, R., 2005, 'Conversion of the pocketbook: The economic project of Luke's Gospel', in R. Kinsler \& G. Kinsler (eds.), God's economy: Biblical studies from Latin America, pp. 169-201, Orbis books, Maryknoll, New York, NY.

Lande, C.H., 1977, 'The dyadic basis of clientism', in S.W. Schmidt (ed.), Friends, followers and factions: A reader in political clientism, pp. 13-37, University of California Press, Berkeley, CA.
Longenecker, B.W., 2010, Remember the poor: Paul, poverty, and the Greco-Roman world, Eerdmans, Grand Rapids, MI.

Lorencin, I., 2007, 'Hospitality versus patronage: An investigation of social dynamics in the third epistle of John', PhD dissertation, Andrews University.

Malina, B.J., 1981, The New Testament world: Insights from cultural anthropology, John Knox Press, Atlanta, GA.

Malina, B., 1988, 'Patron and client: The analogy behind synoptic theology', Forum $4(1), 2-32$.

Malina, B.J., 1987, 'Wealth and poverty in the New Testament and its world', Interpretation 4, 354-367. https://doi.org/10.1177/002096438704100403

Meeks, W.A., 1983, The first urban Christians: The social world of the Apostle Paul, Yale University Press, New Haven, CT.

Megbelayin, I.O., 2001, 'A Socio-rhetorical analysis of the Lucan narrative of the Last supper', PhD thesis, ST Paul University Ottawa.

Metzger, J.A., 2007, Consumption and wealth in Luke's travel narrative, Biblical Interpretation Series 88, Brill, Boston, MA.

Moxnes, H., 1988, The economy of the kingdom: Social conflict and economic relations in the gospel of Luke, Fortress, Philadelphia, PA.

Moxnes, H., 1991, 'Patron-client relationships and the new community in Luke', in J. Neyrey (ed.), The social world of Luke-Acts, models for interpretation, pp. 241-268, Hendrickson, Peabody, MA

Ngele, O.K., Uwaegbute, K.I. \& Odo, D.O., 2017, 'Reading the parable of the rich barn builder in Luke 12: 13-21 in the context of problem of materialism in contemporary Nigerian Christianity', Missionalia 45(3), 285-300. https://doi. contemporary Nigerian
org/10.7832/45-3-206

Neyrey, J.H., 2004, Render to God: New Testament understandings of the divine, Fortress Press, Minneapolis, MN.

Neyrey, J.H., 2005, 'God, benefactor and patron: The major cultural model for interpreting the deity in Greco-Roman antiquity', Journal for the Study of the New Testament 27(4), 465-492.

Oakman, D.E., 1986, Jesus and the economic questions of his day, The Edwin Mellen Press, New York, NY

Oakman, D.E., 1991, 'The countryside in Luke-Acts', in J. Neyrey (ed.), The social world of Luke-Acts, models for interpretation, pp. 151-180, Hendrickson, Peabody, MA.

Oakman, D.E., 2008a, Jesus and the peasants, Cascade Books, Eugene, OR.

Oakman, D.E., 2008b, 'Jesus and Agrarian Palestine: The factor of debt', in J.H. Neyrey \& E.C. Stewart (eds.), The social world of the New Testament: Insights and models, pp. 63-82, Hendrickson, Peabody, MA.

Oakman, D.E., 2014, Jesus, debt and the Lord's prayer: First-century debt and Jesus' intensions, James Clarke, Cambridge.

Patella, M.F., 2009, 'The gospel according to Luke', in D. Durken (ed.), New Collegeville Bible commentary, pp. 215-310, New Testament, Liturgical press, Collegeville, PA.

Phillips, T.E., 2001, Reading issues of wealth and poverty in Luke-Acts, Studies in the Bible and Early Christianity 48, Edwin Mellen Press, Lewiston, ME.

Pilgrim, W.E., 1981, Good news to the poor, Augsburg, Minneapolis, MN.

Porter, L.E., 1988, 'Luke', in F.F. Bruce (ed.), International Bible Commentary, pp. 1182-1228, Zondervan, MI.

Reich, K.A., 2011, Figuring Jesus: The power of rhetorical figure of speech in the gospe of Luke, Brill, Leiden.

Santos, N.F., 2008, 'Family, patronage, and social contests: Narrative reversals in the gospel of Mark', Scripture and Interpretation 2(2), 200-224.

Schottroff, L. \& Stegemann, W., 1986, Jesus and the hope of the poor, Orbis Books, Maryknoll, New York, NY

Seccombe, D.P., 1982, Possessions and the Poor in Luke-Acts, Studienzum Neuen Testament und seiner Umwelt, Cambridge University, Linz.

Shelton, J-A., 1988, As the Romans did, Oxford University Press, New York, NY.

Silverman, S., 1977, 'Patronage as a myth', in E. Gellner \& J. Waterbury (eds.), Patrons and clients in Mediterranean societies, pp. 7-19, The Centre for Mediterranean studies of the American Universities Filed Staff, London.

Utley, B., 1996, Luke the Historian: The Gospel of Luke, viewed 10 June 2020, from www.freebiblecommentary.org.

Uwaegbute, K.I., 2019a, 'A social-scientific Reading of Luke 4:16-19 and the problem of ethnic minorities in Nigeria', Neotestamentica 53(1), 101-121. https://doi org/10.1353/neo.2019.0014

Uwaegbute, K.I., 2019b, 'Material possessions in the gospel of Luke and their implications for Christians in Enugu State', PhD thesis, University of Nigeria, Nsukka.

Van Eck, E., 2009a, 'When patrons are patrons no more: A social scientific reading of the rich man and Lazarus', HTS Teologiese Studies/Theological Studies 65(1), a309. https://doi.org/10.4102/hts.v65i1.309

Van Eck, E., 2009b, 'Interpreting the Parables of the Galilean Jesus: A social-scientific approach', HTS Theological Studies 65(1), 310-321. https://doi.org/10.4102/hts. v65i1.308

Vyhmeister, N.I., 1995, 'The rich man in James 2: Does ancient patronage illumine the text?', Andrews University Seminary Studies 33(2), 265-283.

Wallace-Hadrill, A., 1989, Patronage in ancient society, Routledge, London. 